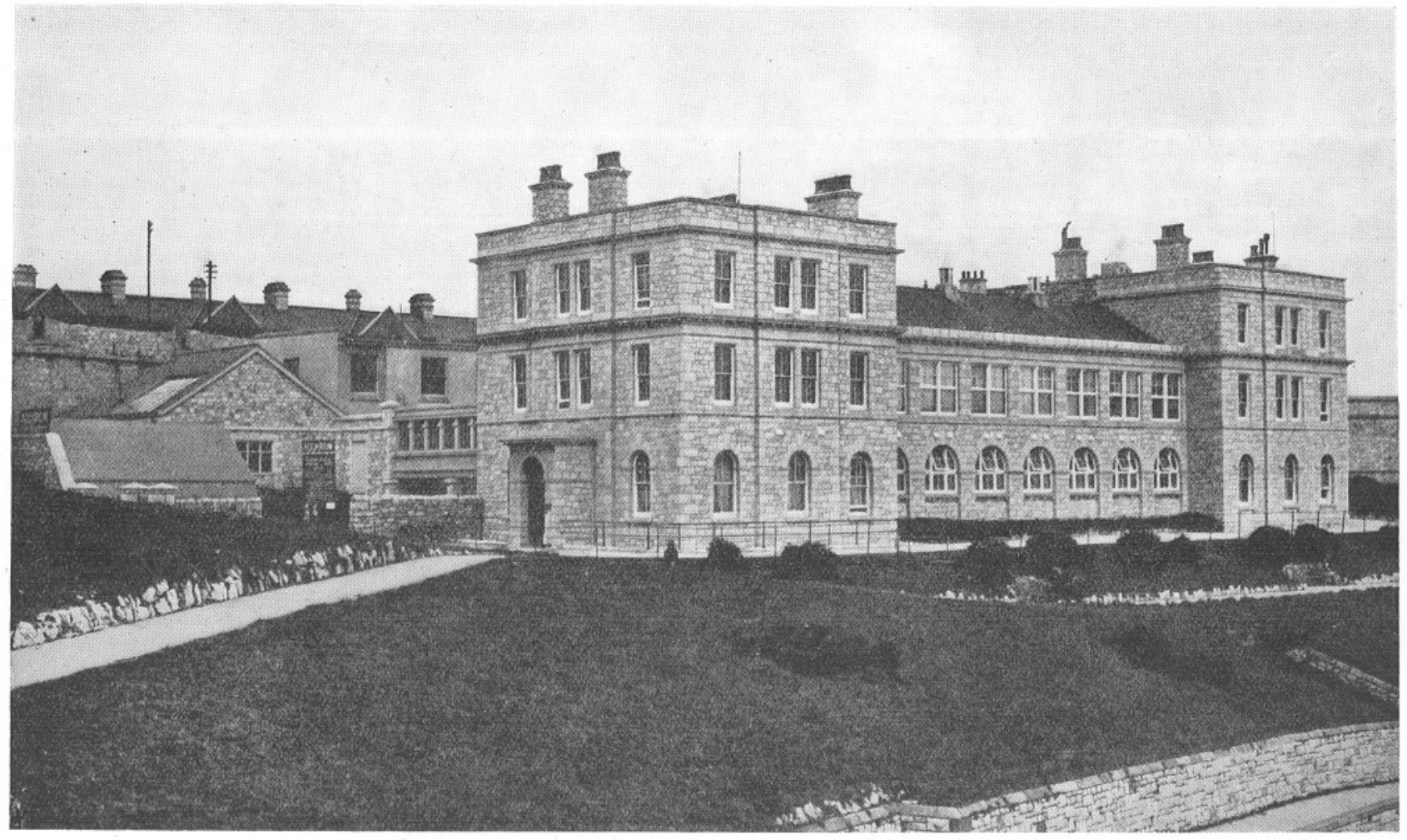




\title{
The Laboratory of the Marine Biological Association at Plymouth.
}

By

\author{
E. J. Allen and H. W. Harvey.
}

With Figures 1 to 7 and Plans I to VII.

The Marine Biological Association of the United Kingdom, to whom the Plymouth Laboratory belongs, is a corporate body of subscribing members, interested in scientific investigations concerning the habits and lifehistories of food fishes and other marine animals. The Laboratory is managed by a Council elected annually by the members of the Association.

The Association was founded in 1884 - when through the energy and initiative of its present President, Sir E. Ray Lankester, a meeting was held in the rooms of the Royal Society of London at which the chair was taken by Professor Huxley, at that time President of the Royal Society. The meeting was attended by many of the leading scientific men of that day, including Sir John Lubbock (afterwards Lord Avebury) and Sir Joseph Hooker, as well as by a number of public men interested in the sea fisheries of the country. The purpose which the founders of the Association had in mind is well expressed in the first resolution adopted by this meeting, which emphasises the necessity for the establishment of one or more laboratories on the British coast, " where accurate researches may be carried on leading to the improvement of zoological and botanical science, and to an increase of our knowledge as regards the food, life, conditions, and habits of British food fishes and molluses in particular, and the animal and vegetable resources of the sea in general." The policy indicated in this resolution has been consistently followed by the Association throughout its history, and it has endeavoured to aid at the same time science and industry. Research having a direct bearing on the fishing industry has been carried on side by side with research in pure science, and the two have mutually helped and supported each other.

The Laboratory (Fig. 1), situated below the wall of the Citadel, overlooking Plymouth Sound, was opened in June, 1888, with a staff consisting of a Director, a Naturalist, and one scientific assistant. This permanent staff, which is engaged all the year round in research work, has gradually increased until at the present time it numbers thirteen scientific 
workers. In addition, over thirty working places are available for visiting research workers from British Universities and abroad.

During its early years the Laboratory had to depend largely on the contributions of voluntary subscribers and on grants from the Fishmongers' Company and from scientific societies for its annual income. From the commencement, also, it received an annual grant from the Government, which during the first five years amounted to $£ 500$. This grant was then increased to $£ 1000$, at which figure it remained for many years. In 1902 the Association was asked by His Majesty's Treasury to undertake the English scientific investigations in connection with the International Council for the Study of the Sea, an organisation to which the British Government had adhered with a view to co-operating with other European Governments in a comprehensive programme of research into the natural history of marketable marine fishes, of their migrations, and of the great fluctuations which occur in their abundance from year to year. These researches included investigations of the water movements, especially of the North Sea and English Channel, of the distribution of plankton, and of the invertebrate fauna upon which the fishes feed. In connection with the work, which continued in the hands of the Association until 1910, an auxiliary laboratory was established at Lowestoft, and the steam trawler Huxley became available, largely through the generosity of Dr. G. P. Bidder, for work in the North Sea. During this period and in the following years the Association owed much to Sir Arthur Shipley, who occupied the position of Chairman of the Council.

After the great war Government grants for fishery research were put under the control of the Development Commissioners. The Laboratory at Lowestoft was re-established under the Ministry of Agriculture and Fisheries for the purpose of studying problems having a direct bearing on the commercial fisheries. At the same time a substantially increased grant was made to the Marine Biological Association for the maintenance of the Plymouth Laboratory, so that researches of a more general or fundamental nature concerning life in the sea might be developed upon a larger plan. With the help of this grant the steamer Salpa (Fig. 7), a steam-drifter fitted for trawling, was purchased by the Association from the Admiralty for work at Plymouth, and subsequently a motor boat was obtained for use in inshore waters. In order to give adequate facilities for the larger staff and the increasing number of visiting research workers, an addition was made to the Laboratory buildings in 1920, this being made possible by the generosity of a number of friends of the Association, including once more the Fishmongers' Company and various scientific societies. A temporary building was put up in 1922 to provide accommodation for the students attending the Easter course in marine biology, which has been held at the Laboratory for many years, this building being paid for 
chiefly by subscriptions from past students. About this time also the use of some sheds, and a small cove, which has since been converted into a sea pond for experimental work, was secured for a nominal rental at Pier Cellars, Cawsand Bay.

At the inaugural meeting of the Association attention was drawn by Mr. G. J. Romanes to the wide field of research offered by the physiology of marine organisms. Later the work of Keith Lucas and of Mines, much of which was carried out at Plymouth, showed how valuable were the facilities provided by the Laboratory for such research, and with the advance of this branch of biology during the last two decades the attention of a growing number of physiologists has turned to the possibility of attacking many fundamental problems by experiments upon the tissues of simple marine animals, a method of attack which seems likely to assist in the interpretation of results hitherto confined chiefly to land vertebrates. The opening of this field of enquiry was followed by the realisation of the wide possibilities of Comparative Physiology in the study of animals of diverse evolutionary descent. No environment yields more representatives of the different animal groups than the sea.

The constant supply of marine animals almost daily by the steamer and motor boat or from the Aquarium, made the Plymouth Laboratory particularly suitable for such research, and the numbers of visitors from the staffs of various Universities working during the Easter and summer vacations severely taxed the accommodation provided by the existing buildings. Through the generosity of numerous benefactors, many of them former workers in the Laboratory, of the Fishmongers' Company, and of the International Education Board a sufficient sum was collected to erect a new wing. This was completed in 1926 and contains seven private laboratories for visiting research workers, a physiological and a chemical laboratory, and cellars for galvanometer or constant temperature work.

The Laboratory as a whole, therefore, now offers facilities for all kinds of biological research, and these facilities have been utilized by numerous investigators from both British and Foreign Universities. The international character of the work has recently shown a marked increase, and the personal contacts with research workers from abroad is a great stimulus to the Association's scientific staff.

An idea of the volume and wide scope of the investigations may be gained by referring to the long list of published original contributions to science, which have emanated from the Laboratory (Journ. Mar. Biol. Assoc., XV, 3, p. 753). In addition to those who have worked at some particular problem and published the results of their investigations, there is a constant and increasing stream of visitors from all countries, who come for short visits to discuss matters appertaining to their own researches 
or to follow the various investigations in progress. This is a feature of the activities of the Association of no little benefit, for it not only aids the co-ordination of research, but brings those working in the Laboratory into close touch with progress taking place elsewhere.

A further activity of the Association is the supply of specimens of marine animals and plants to biologists in this and other countries, both for research and for teaching purposes. Expeditions and individual naturalists are also supplied with nets, dredges, and apparatus constructed and tested un ter the supervision of the staff.

\section{The Buildings and Equipment.}

(See Figs. 2-5 and Plans I-VII.)

The original building contains a general laboratory (Fig. 2) with cubicles and a series of small aquaria for the use of the staff or visitors engaged

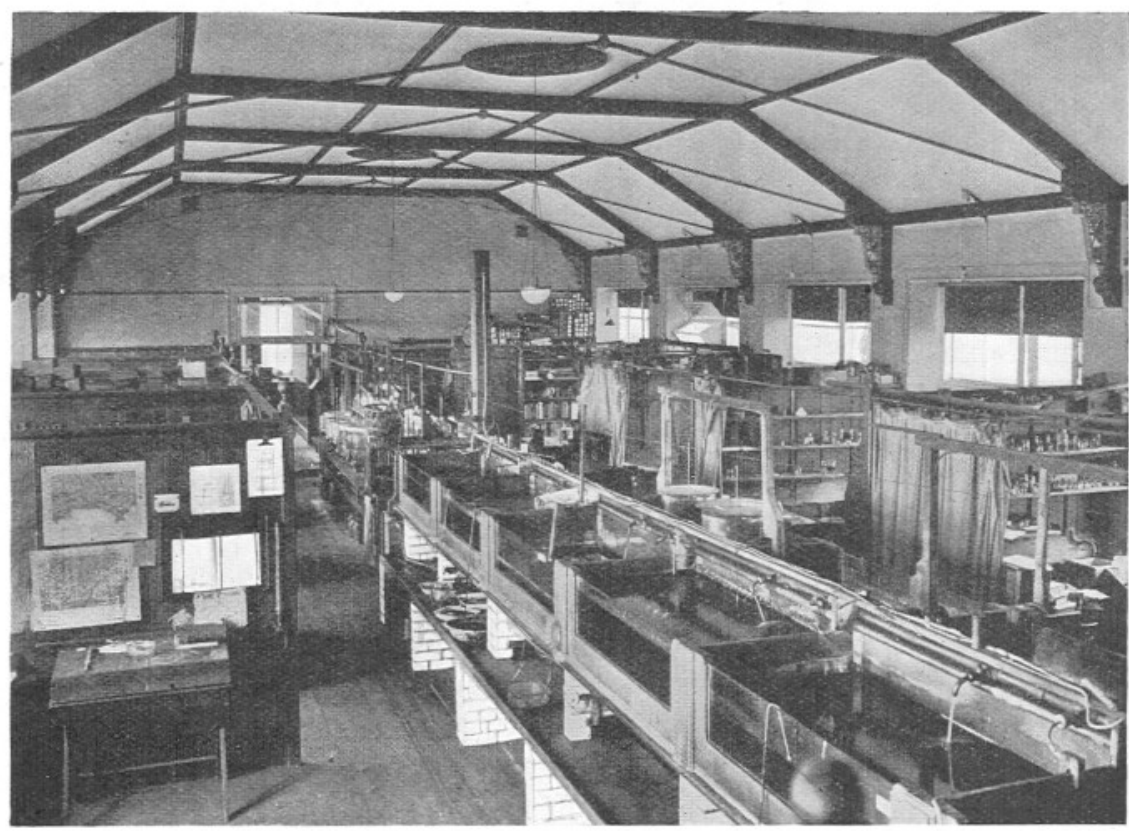

Fig. 2.-The General Biological Laboratory.

in zoological investigations; an aquarium on the ground floor which is open to the general public ; an extensive library of biological publications, including the leading physiological and biochemical journals (Fig. 3); a residence for the Director ; four or five small laboratories ; an office ; and living-quarters for the engineer-caretaker. The general arrangement 
is shown in Plans I-VII. It is connected with the Allen Building and new wing by a bridge. The Allen Building, $34 \mathrm{ft}$. by $24 \mathrm{ft}$., is divided into two laboratories by a temporary partition. In it are housed a type collection of the local marine fauna and flora and apparatus for obtaining photographic records of specimens, etc. A photographic dark room is attached.

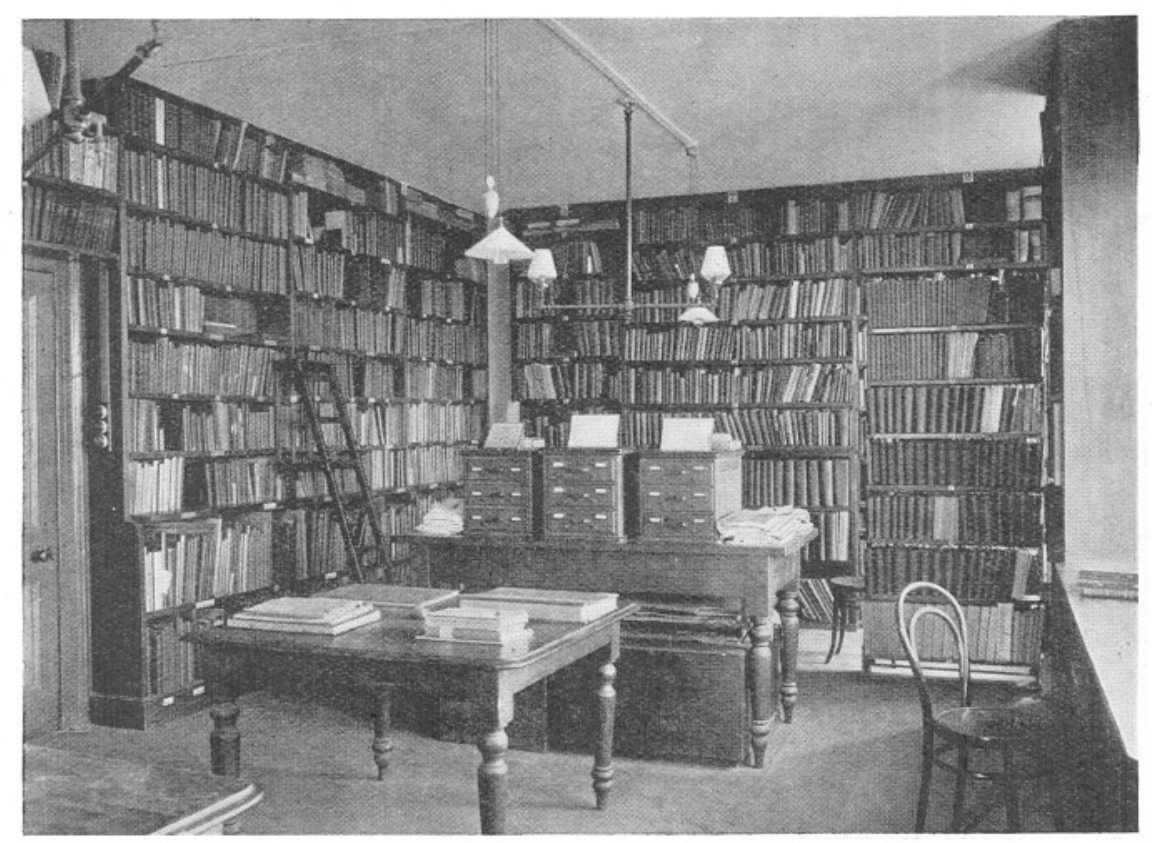

Fig. 3.-The Library.

In the new wing, the chemical laboratory is well equipped with apparatus of general utility, including ovens, analytical balances, tube and muffle furnaces. There is a large and varied stock of chemicals. The physiological laboratory (Fig. 4) is equipped with kymographic and respiration apparatus, spectroscopes, small electric motors, and temperature baths. Gas, water, and compressed air are led to these and to the seven private laboratories, and alternating electric current, at 210 volts, can be taken from numerous points. In addition, direct current up to 100 volts may be supplied when required from a dynamo situated in the cellars of the main building. A supply of ice, liquid air, and of compressed oxygen can be obtained at short notice in the town. On the ground floor provision is made for the reception of dredging and other material brought in by the boats, and a constant supply of sea-water is provided by means of a motor pump from one of the reservoirs (Fig. 5). 
The building (Plan I), in which a course of marine biology is held for a month during the Easter vacation, is fitted with gas, water, and electric light, accommodates eighteen to twenty students engaged in microscopic and faunistic work, or about twelve post-graduate students engaged in general physiological technique, for whom a class is held at the end of the summer vacation.

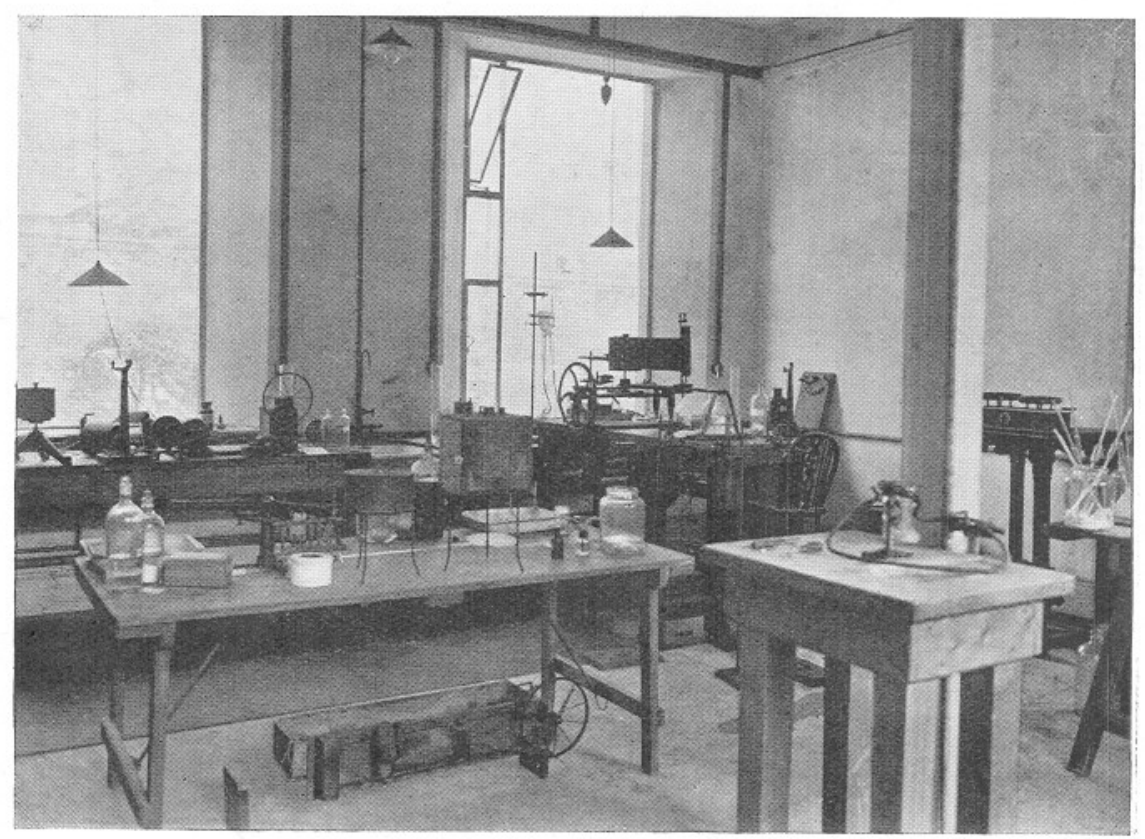

Fig. 4.-The Physiological Laboratory.

The Aquarium and Sea-water Tanks (Fig. 6).

The Aquarium or tank room, measuring $70 \times 34 \frac{1}{2} \mathrm{ft}$., and situated on the ground floor of the main building, is open to the public at a small charge and to fishermen and to parties of school children free of charge. It contains a representative collection of the commoner fishes and invertebrate animals found in the south-western area of the English Channel, and a small collection of fresh-water fishes (Fig. 6).

The tanks are built of slate, with glass fronts fitted against cast-iron frames. On the south side are nine tanks, $4 \mathrm{ft}$. wide and $4 \mathrm{ft}$. deep, one being $15 \mathrm{ft}$. long, two $10 \mathrm{ft}$., and the remaining six $5 \mathrm{ft}$. long. On the north side are three tanks each $5 \mathrm{ft}$. deep, one being $30 \mathrm{ft} .6 \mathrm{ins}$. long $\times 9 \mathrm{ft}$. wide, one $15 \mathrm{ft}$. $6 \mathrm{in}$. long $\times 9 \mathrm{ft}$. wide, and one $15 \mathrm{ft}$. long $\times 5 \mathrm{ft}$. wide. In the centre are a row of five glass-fronted "table tanks," $1 \mathrm{ft} .9$ ins. 
deep $\times 2$ ft. 3 ins. wide, and $9 \mathrm{ft} .9$ ins. long, several of them being divided into two by transverse partitions. The height of these tanks is $4 \mathrm{ft}$. above ground level, so their contents can be examined from above as well as through the glass front. In addition to these fixed tanks a number of small wooden aquaria have been added, and a collection of preserved specimens of general interest is displayed on the east and west walls.

A guide book has been prepared, and is on sale at $1 /-$ per copy, giving a simple account of the life-history and habits of most of the sea creatures living in the Aquarium.

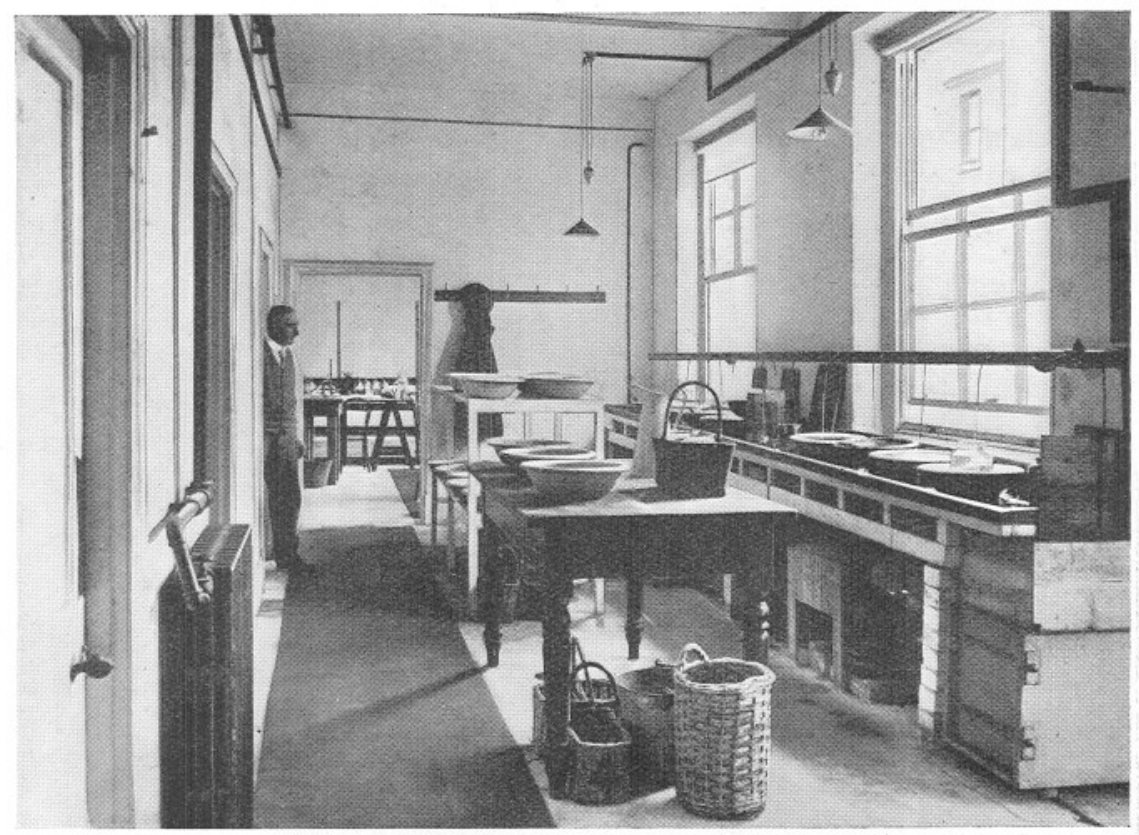

Fig. 5.-Reception of Material and Sea-water Circulation.

Twelve glass-fronted tanks, $1 \mathrm{ft} .6$ ins. deep, $2 \mathrm{ft} .3$ ins. wide, and $4 \mathrm{ft}$. 8 ins. long, are installed in the general laboratory above the tank room, and also a shallow wooden table tank, $8 \mathrm{ft}$. by $5 \mathrm{ft} .6$ ins. and 8 ins. deep.

In the yard behind the Aquarium there is a brick-work tank lined with asphalte, $18 \mathrm{ft} . \times 3 \mathrm{ft} . \times 1 \mathrm{ft}$. $10 \mathrm{ins}$. deep, in which animals are kept as a reserve from which to replenish specimens in the Aquarium, or for use by workers in the Laboratory. Since the opening of the Aquarium of the Zoological Society in London a large number of marine animals have been collected and acclimatised to life under aquarium conditions in the . Plymouth tanks and then despatched to Regent's Park. 
A wooden table, $24 \mathrm{ft}$. long, coated with asphalte, is also placed in this yard ; on it glass or other vessels containing living animals can be kept under a continuous flow of sea-water from a launder situated above the table.

Both outside tanks and table are protected from rain by galvanised iron roofing, and are not subjected to direct sunshine.

Most of the tanks are aerated for about 20 hours daily from a compressed air supply at 5 lbs. per square inch pressure, which is led to the bottom of each tank and issues through a porcelain or cane nozzle, the air being thus delivered in streams of minute bubbles.

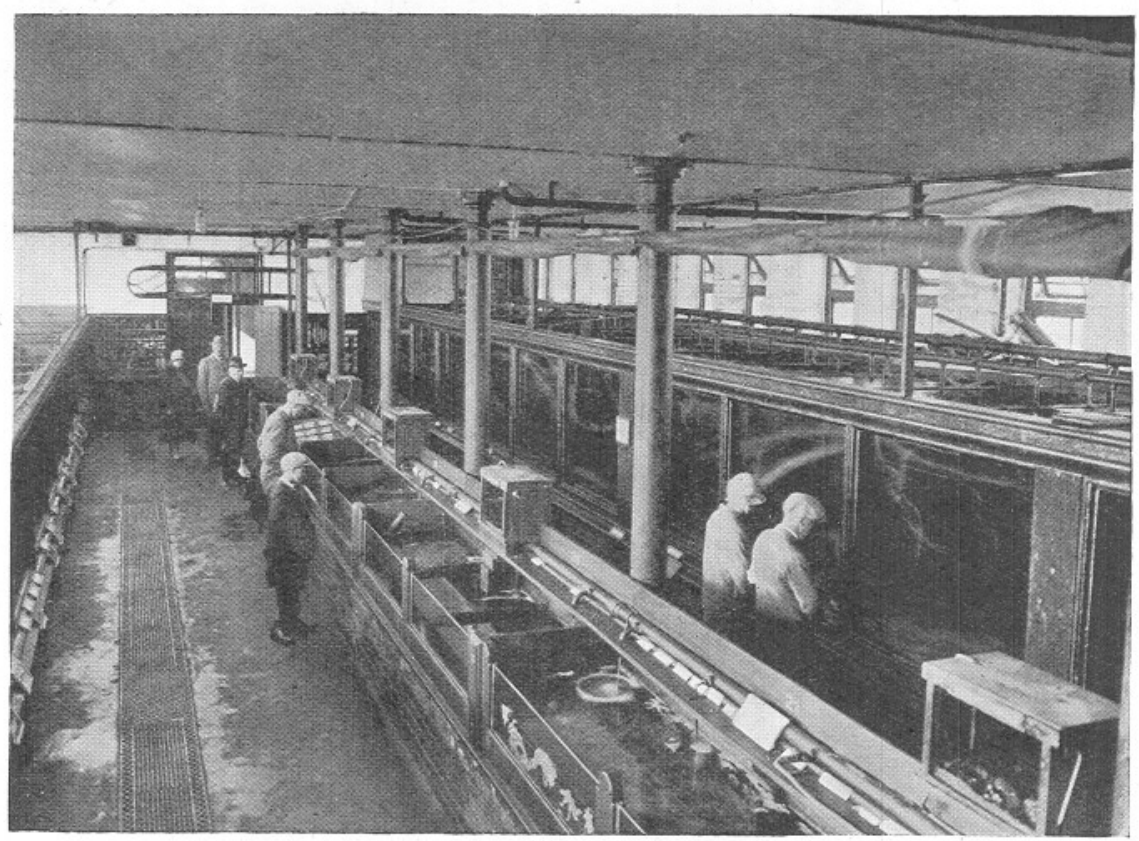

Fig. 6.-The Aquarium.

\section{The Supply and Circulation of Sea-Water to the AquARIUM TANKS.}

Behind the main building and below ground level are two concrete reservoirs, asphalte lined, $37 \mathrm{ft} .6 \mathrm{in}$. long, $21 \mathrm{ft} .6$ ins. wide, $11 \mathrm{ft}$. deep, and each capable of holding 55,000 gallons of water. These are filled with sea-water from a well, built in the rocks on the shore below the Laboratory, which has a depth of about $14 \mathrm{ft}$. at high tide. A Shone's Ejector in the bottom of the well is supplied with compressed air which forces the water

- up to the reservoir through a 4-in. cast-iron pipe enamelled inside. The ejector was installed in 1887 and is still working. 
These reservoirs are entirely cleaned out and refilled at comparatively long intervals ; losses are made up and a proportion of the water replaced by pumping in fresh sea-water at high tides during the summer, when conditions are most favourable. An increase in salinity up to 37 parts per thousand is not found to be detrimental to the animals in the tanks.

The water in one reservoir is pumped to the Aquarium tanks for about 20 hours daily for one week, through a system of vulcanite pipes supplied with nozzles several inches above the level of water in the tanks. It is forced through these nozzles in jets which carry air in fine bubbles deep into the tanks. The water overflowing is carried by culverts back to the reservoir.

At the expiration of a week the circulation is changed over to the other reservoir. In the resting reservoir particles of suspended matter in the water fall to the bottom. The hydrogen ion concentration of the circulating water is kept close to that in the open sea by addition of two pounds of lime to each reservoir every second week. For forty years this circulation has never failed for long enough to cause the death of fish in the Aquarium, although for nearly thirty years it was maintained by original "Otto" gas engines, capricious in their behaviour and exacting much attention.

For the last five years two alternative methods of circulation have been used. (1) By a cast-iron 2-in. centrifugal pump driven directly by a 3-h.p. electric motor. This is designed to deliver 2,500 gallons per hour against a head of 35 feet. The motor also drives, through gearing, a rotary air compressor delivering 7 cubic feet of free air per minute at a pressure of 5 lbs. to the square inch. (2) By one of a pair of cast-iron 2-in. centrifugal pumps driven from shafting by a 5-h.p. gas engine. A small air compressor is also driven from the same shafting, and an independent air compressor driven by its own electric motor has recently been fixed.

The compressed air supply to the Shone's Ejector, pumping water from the sea into the reservoirs, is obtained by an air compressor driven from the 5-h.p. gas engine. This can be added to by compressed air from a compressor built in one unit with a 4 h.p. " Otto " gas engine installed forty years ago and still functioning.

\section{The Ship and Motor Boat.}

The s.s. Salpa (Fig. 7) is a wooden steam drifter $88 \mathrm{ft}$. long, 19.9 ft. beam drawing $10.5 \mathrm{ft}$. aft and $5 \mathrm{ft}$. forward, built in 1918 and capable of a speed of $9 \frac{1}{2}$ knots. She is equipped with a steam winch for trawling and a small deckhouse laboratory. A 60 -ft. otter trawl is carried, together with various small trawls, dredges, and plankton nets. During most of the 
year the ship works daily from Plymouth, longer cruises being made from time to time.

The motor boat Gammarus, $25 \mathrm{ft}$. long and $8 \mathrm{ft}$. beam, drawing $2 \mathrm{ft}$. 9 ins. and propelled by two 3-h.p. Kelvin engines, works daily in and around Plymouth Sound.

\section{Provision for Visitors and Students Working IN the LABORATORY.}

The accommodation provided for visitors includes cubicles, separate rooms, or bench space with adequate fittings for biochemical and physio. logical work, the use of all ordinary glassware, chemicals, and apparatus of a general nature. The Association undertakes, as far as possible, to supply the animals or plants or water samples required for any investigation, or such facilities for obtaining them as may be at the command of the Laboratory.

Microscopes are not usually provided. Intending visitors are advised to write to the Director stating the nature of the investigations which they propose to carry out and the apparatus which they will require. Every effort is made to provide any special apparatus which is needed, and to collect the animals wanted for research.

The Laboratory is open for research during the entire year, including holidays, and workers are provided with a key so that they may work at night when they desire to do so. The fishermen are engaged in the collection of material daily, except on Sundays and for three or four days at Christmas and Easter. The services of a laboratory assistant are available if necessary.

The facilities are primarily intended for visitors who are engaged in their own research or wish to collaborate with members of the staff who are investigating some particular problem of biological science. Every effort is made by the staft to give information and assistance.

With regard to the admission of research workers from the Dominions, from foreign Universities, and members of Government departments who desire to make use of this Laboratory, the Council of the Association are usually willing to remit all charges, welcoming such visitors as guests. Research workers from this country may be nominated in many cases to occupy working space in the Laboratory free of charge; Founders and Governors of the Association have the privilege of making such nominations. Accommodation may also be rented at 50 guineas per year, 5 guineas per month, or thirty shillings per week. Particulars regarding nominations, copies of the regulations and lists of recommended lodgings in the vicinity are supplied on application to the Director.

A course of study in marine biology is held during the Easter vacation 


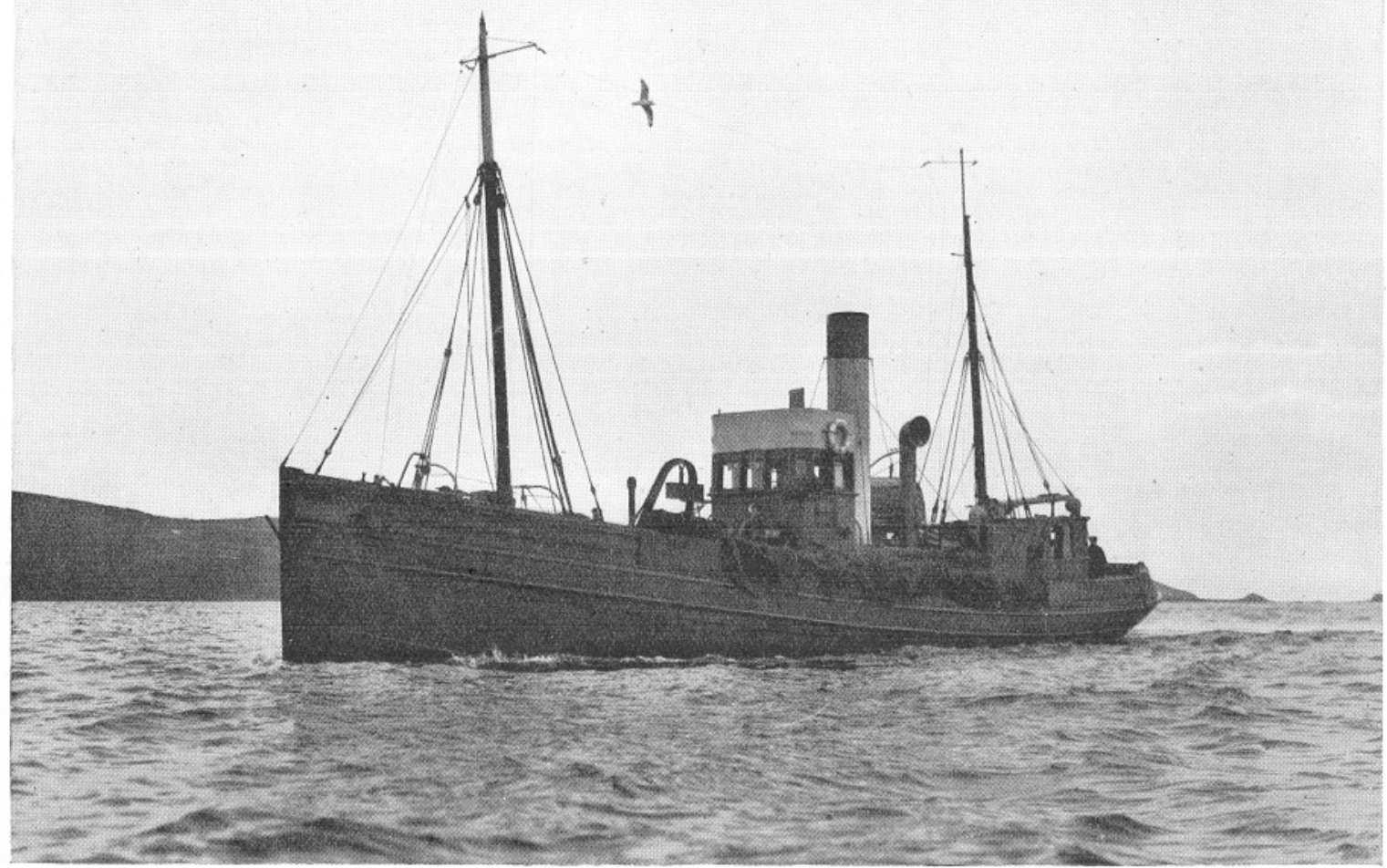

Fig. 7.-The "SALPa." 
of the Universities. In this course advanced and post-graduate students are given the opportunity for practical study of the structure and lifehistories and habits of marine organisms. The more general aspects of marine biology are studied in collecting expeditions on the shore and in the s.s. Salpa and the motor boat. The characteristics of the shore fauna on sandy, muddy, and rocky bottoms in sheltered and exposed places are demonstrated on well-known grounds in the neighbourhood. The varied geological nature of the Devon and Cornwall shore line supports an extensive and varied fauna, which is exposed by the considerable rise and fall of the tide. The use of tow-nets, dredges, and trawls employed in investigating the plankton and the fauna and flora of the sea bottom is explained and demonstrated. A special study is made of the chief larval stages of different groups of the animal kingdom, and simple artificial fertilisations are made to obtain those stages of development which are rarely taken in the nets.

Another course is held in late summer for post-graduate students commencing research in comparative physiology, who wish to explore the possibilities of attacking various outstanding problems by means of experiments on marine animals, and for zoologists who desire to become conversant with physiological methods and apparatus and the possibilities of their application to problems concerning physiological processes.

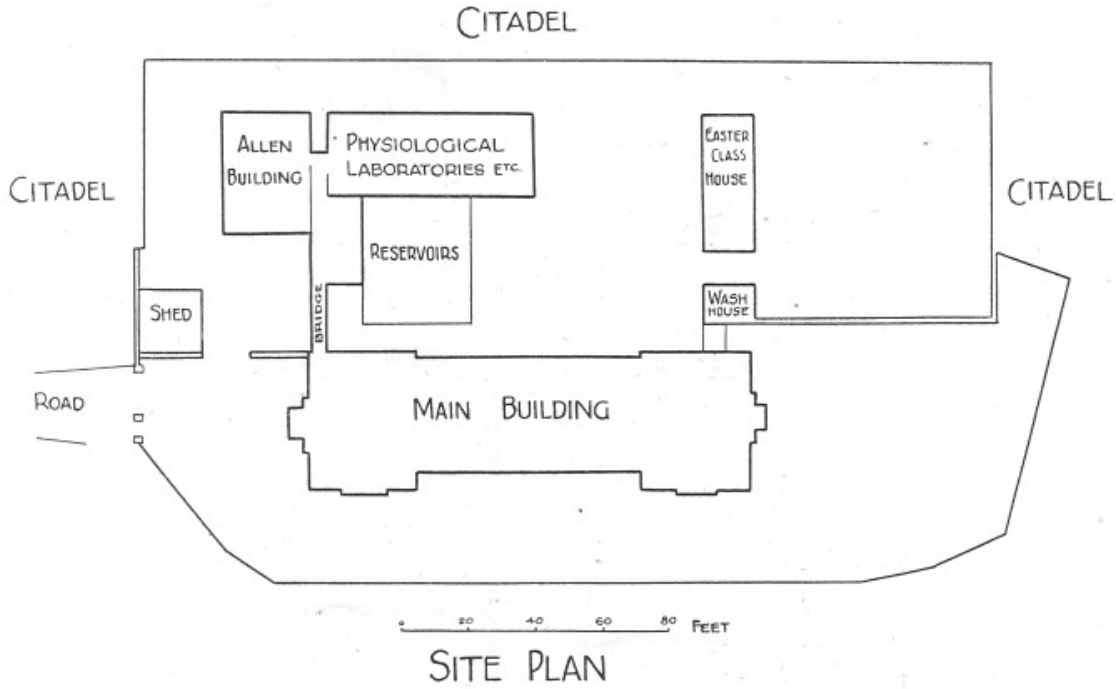

Plan I. 


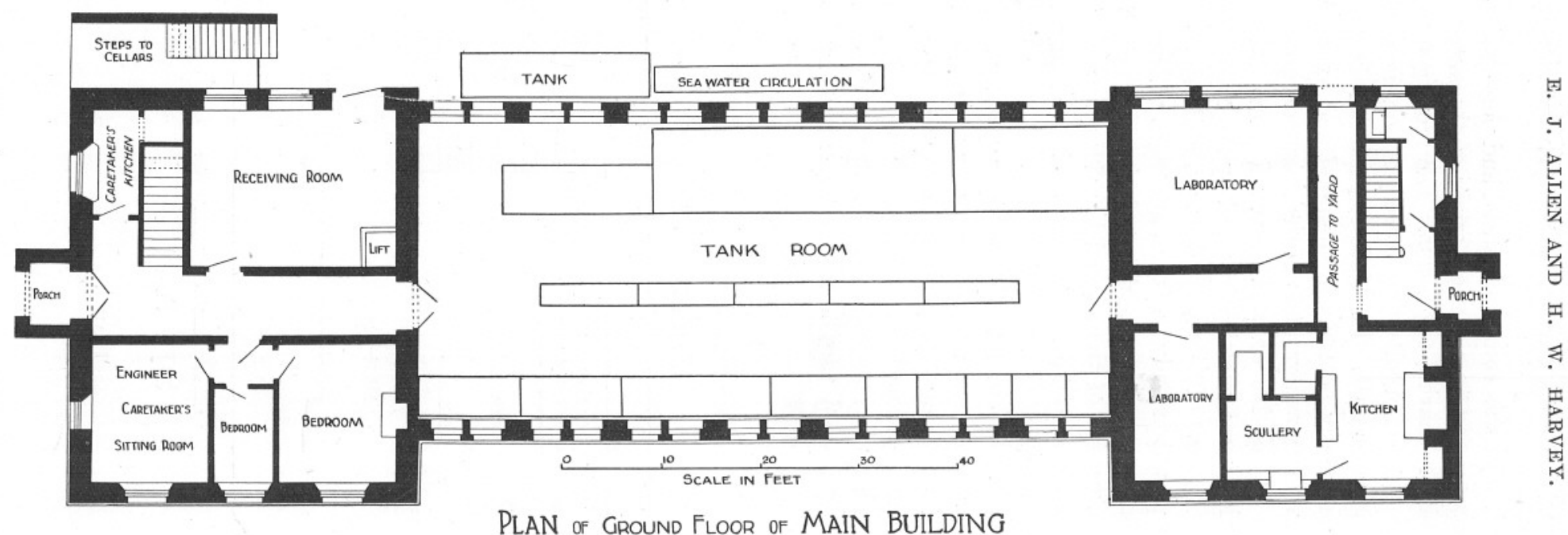

Plan of Ground Floor of MAIN BUILDING

Plan II. 


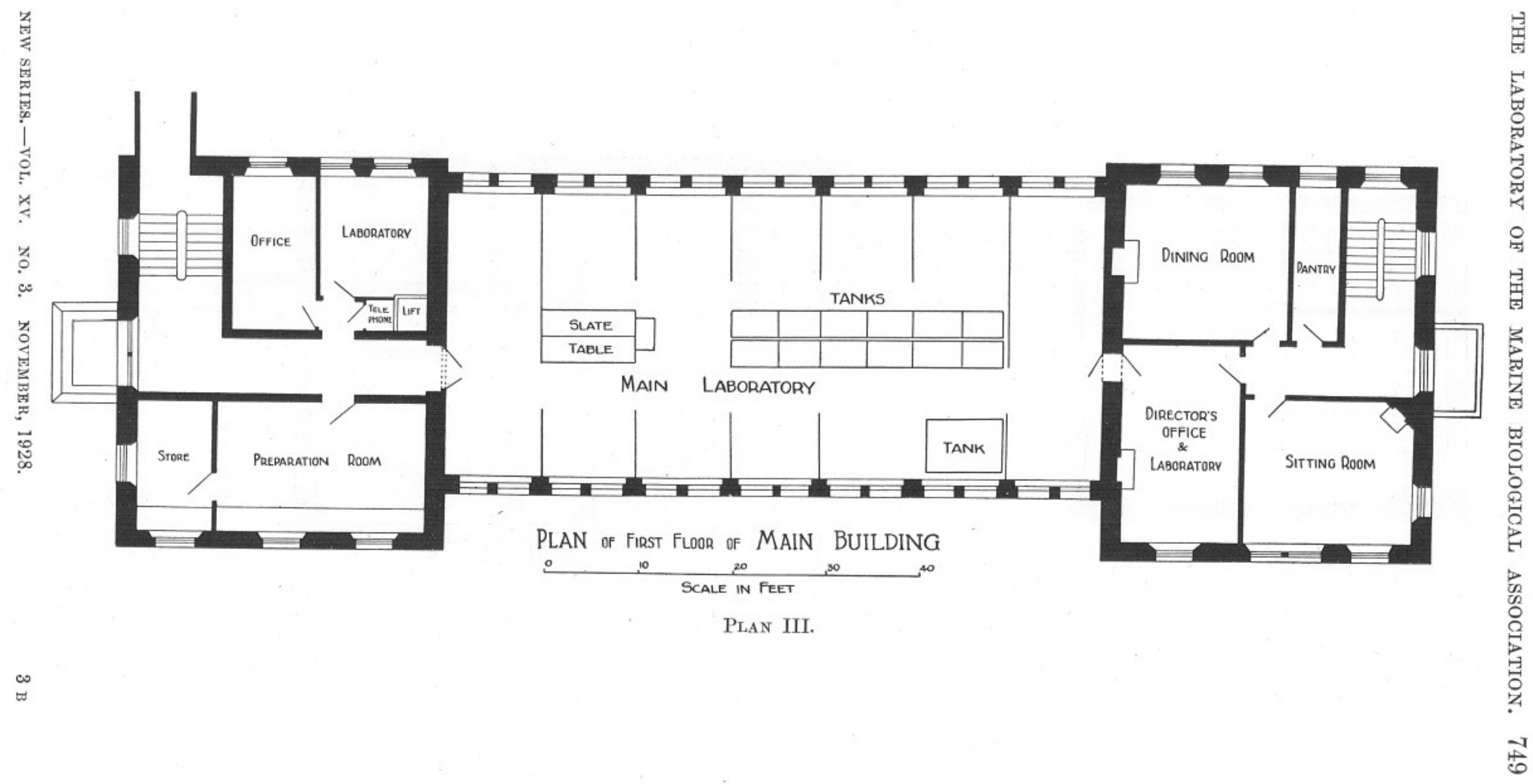




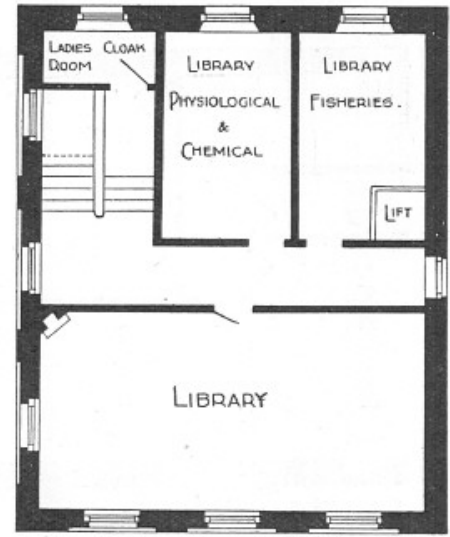

SECOND FLOOR OF WEST WING OF MAIN

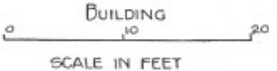

Plan IV.

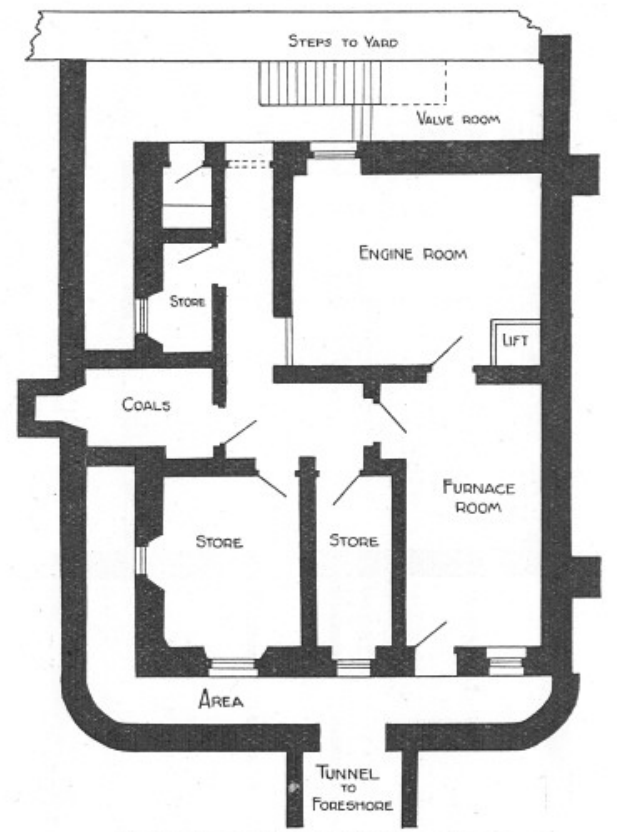

Basement of West Wing of Main

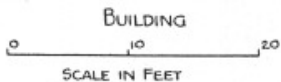

Plan V. 

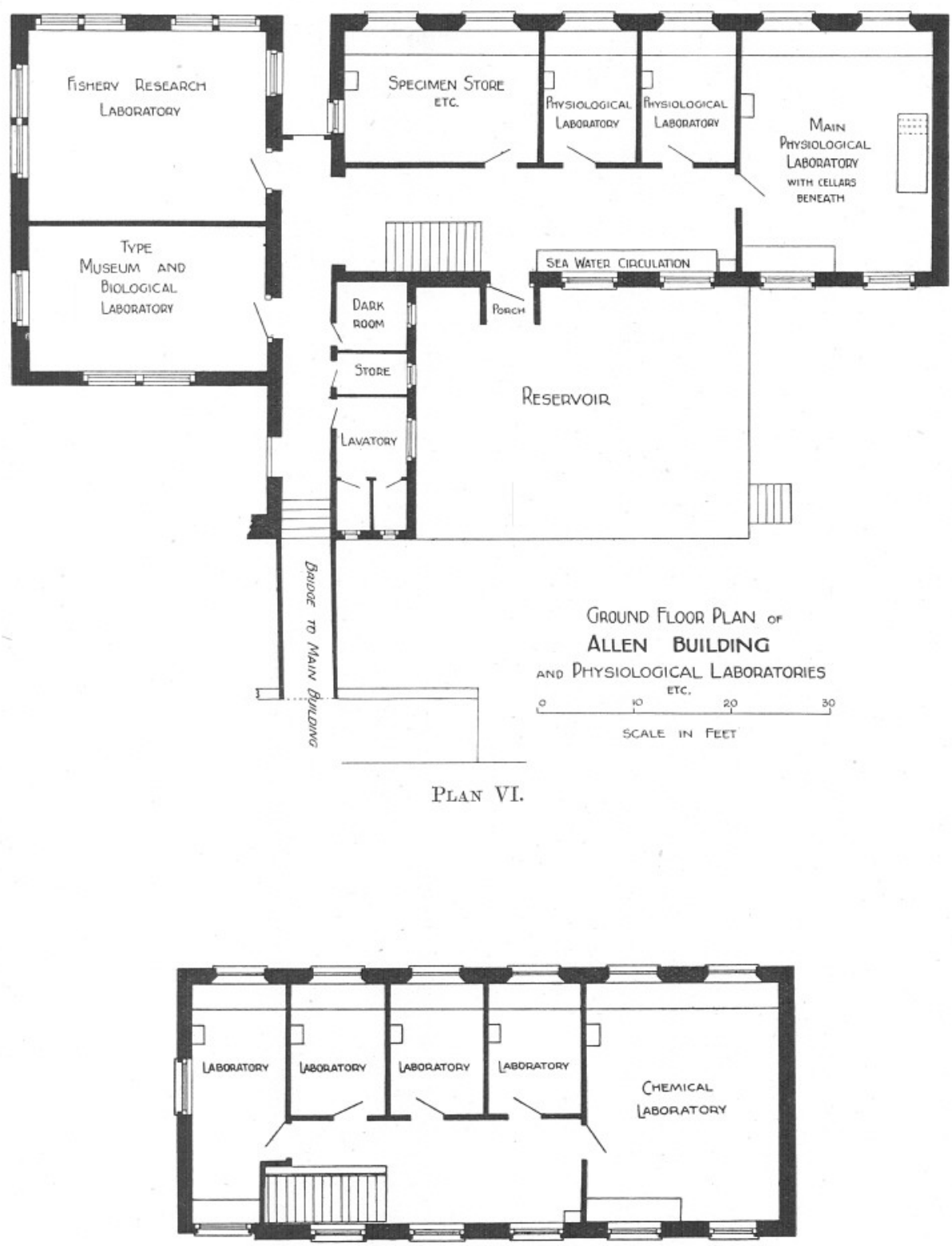

First floor of Phisiological Laboratories Etc.

운 STA IN FET so

PLAN VII. 